\title{
DspA/E, a Type III Effector Essential for Erwinia amylovora Pathogenicity and Growth In Planta, Induces Cell Death in Host Apple and Nonhost Tobacco Plants
}

\author{
Tristan Boureau, ${ }^{1}$ Hayat ElMaarouf-Bouteau, ${ }^{1}$ Amélie Garnier, ${ }^{1}$ Marie-Noëlle Brisset, ${ }^{2}$ Claude Perino, ${ }^{1}$ \\ Igor Pucheu, ${ }^{1}$ and Marie-Anne Barny ${ }^{1}$ \\ ${ }^{1}$ Laboratoire des Interactions Plantes-Pathogènes, UMR217 INRA/INA-PG/Université Paris VI, 16 rue Claude Bernard, \\ 75231 Paris Cedex 05, France; ${ }^{2}$ UMR PaVé INRA/INH/Université d'Angers, Centre INRA d'Angers, 42 rue Georges Morel, \\ BP 60057-49071 Beaucouzé Cedex, France
}

Submitted 12 April 2005. Accepted 2 September 2005.

Erwinia amylovora is responsible for fire blight, a necrotic disease of apples and pears. E. amylovora relies on a type III secretion system (TTSS) to induce disease on hosts and hypersensitive response (HR) on nonhost plants. The DspA/E protein is essential for $E$. amylovora pathogenicity and is secreted via the TTSS in vitro. DspA/E belongs to a type III effector family that is conserved in several phytopathogenic bacteria. In $E$. amylovora, DspA/E has been implicated in the generation of an oxidative stress during disease and the suppression of callose deposition. We investigated the fate of DspA/E in planta. DspA/E delivered artificially to apple or tobacco cells by agroinfection induced necrotic symptoms, indicating that DspA/E was probably injected via the TTSS. We confirmed that DspA/E acts as a major cell-death inducer during disease and HR, because the $d s p A / E$ mutant is severely impaired in its ability to induce electrolyte leakage in apple and tobacco leaves. Expression of the defense marker gene $P R 1$ was delayed when $d s p A / E$ was transiently expressed in tobacco, suggesting that DspA/E-mediated necrosis may be associated with an alteration of defense responses.

The gram-negative bacterium Erwinia amylovora causes fire blight, a necrotic disease responsible for considerable economic losses in plants of the family Rosaceae, especially those of the subfamily Maloidae, which include apple (Malus spp.) and pear (Pyrus spp.). The main disease symptom in host plants is black necrosis of shoots and dark browning of the leaves, resembling fire damage and accounting for the name given to the disease (Van der Swet and Beer 1995). Resistant cultivars exist, however their resistance is complex and cannot be accounted for by a major resistance $(R)$ gene (Lespinasse and Aldwinckle 2000). Concomitantly, no avirulence gene has been described in E. amylovora. In nonhost plants, such as tobacco, E. amylovora elicits a hypersensitive reaction (HR) restricting the growth of the pathogen at the site of inoculation. Genetic studies have demonstrated that the ability of E. amylovora to cause disease in host plants and to elicit the HR in nonhost plants de-

Corresponding author: A. Barny; E-mail: barny @inapg.inra.fr

This paper is dedicated to the memory of our friend and colleague Igor Pucheu, who died on December 26, 2004, at the age of 34. pends on the presence of a functional type III secretion system (TTSS) encoded by the hrp (hypersensitive reaction and pathogenicity) gene cluster (Steinberger and Beer 1988; Barny et al. 1990).

The TTSS is widespread and its structure is well conserved among gram-negative pathogenic bacteria, whether they attack animals (Yersinia, Salmonella, EPEC spp.) or plants (Pseudomonas, Ralstonia, Xanthomonas, Pantoea, Erwinia spp.). The TTSS enables the pathogenic bacteria to inject effector proteins directly into the eukaryotic cell (Cornelis andVan Gijsegem 2000). Once inside the host cell, type III effector proteins modulate and divert the metabolism of the eukaryotic cell towards responses favorable to the pathogenic bacteria (Alfano and Collmer 2004). Recent studies showed that type III effectors of plant pathogenic bacteria can mask the presence of other effectors potentially recognized by the plant (Espinosa et al. 2003; Jackson et al. 1999; Jamir et al. 2004; Tsiamis et al. 2000), suppress basal defenses (DebRoy et al. 2004; Hauck et al. 2003; Keshavarzi et al. 2004), suppress the phenylpropanoid pathway (Venisse et al. 2002), or activate an oxidative burst required to induce disease (Venisse et al. 2001, 2003).

In $E$. amylovora, four proteins secreted by the TTSS in vitro have been characterized, $\operatorname{HrpA}$, HrpN, HrpW, and DspA/E. HrpA is the structural protein of the type III secretion pilus; it forms a hollow structure functioning as a conduit for protein delivery (Jin and He 2001; Jin et al. 2001; Li et al. 2002). HrpN and HrpW belong to the harpin family and are HR elicitors in tobacco (Gaudriault et al. 1998; Kim and Beer 1998; Wei et al. 1992). HrpN has been detected in the intercellular spaces of infected apple seedlings by immunocytochemistry, indicating that $\mathrm{HrpN}$ is secreted in planta (Perino et al. 1999). $\mathrm{DspA} / \mathrm{E}$ is a major candidate effector. DspA/E is homologous to AvrE, a type III effector identified in Pseudomonas syringae pv. tomato that is recognized as an avirulence protein in soybean plant (Lorang and Keen 1995). Functional cross-complementation has been demonstrated between DspA/E and AvrE, although these proteins display only $21 \%$ identity (Bogdanove et al. 1998). This suggests that DspA/E and AvrE play the same basic role during disease. In E. amylovora, DspA/E is central to the disease process, as $d s p A / E$ mutants do not grow on host plants and cannot induce disease symptoms (Barny et al. 1990; Bogdanove et al. 1998; Gaudriault et al. 1997). It was recently shown that the E. amylovora $d s p A / E$ mutant and $P$. syringae pv. tomato $\Delta \mathrm{cel}$ mutant (deleted of four characterized effector 
genes including $a v r E$ ) are unable to suppress callose deposition during disease (DebRoy et al. 2004). DspA/E has also been implicated in the generation of the oxidative stress during disease on host plants, as the $d s p A / E$ mutant is severely affected in its ability to activate plant antioxidant enzymes (Venisse et al. 2003). Whether DspA/E acts alone during these processes remains an open question.

In the present study, we investigated the fate of DspA/E in host and nonhost plants.

\section{RESULTS}

\section{DspA/E belongs to a family}

of type III effectors conserved in plant pathogenic bacteria.

DspA/E homologs were identified by PsiBlast analysis or were obtained from preliminary genome sequence data for $E$. chrysanthemi 3937. Homologs were identified in several gramnegative phytopathogenic bacteria and in the saprophytic bacterium $P$. fluorescens (Fig. 1). Three complete genome sequences are available for Xanthomonas spp. (X. oryzae pv. oryzae, $X$. axonopodis pv. citri, and $X$. campestris pv. campestris), but none were found to contain a DspA/E homolog, suggesting that this type III effector is absent from Xanthomonas species.

To analyze the relationship between the various DspA/E homologs, we used the method of maximum parsimony to construct a phylogenetic tree. The phylogenetic tree was congruent with overall bacterial phylogeny, suggesting that DspA/E is not a target for frequent horizontal transfer (Fig. 1). Indeed, in all but two cases ( $R$. solanacearum and $E$. chrysanthemi), the gene encoding the $d s p A / E$ homolog was found to be adjacent to the genes of the type III secretion cluster, in the conserved effector locus as defined in Pseudomonas spp. (Alfano et al. 2000), suggesting this gene coevolved with the genes encoding the TTSS.

Depending on the plant-bacterium interaction considered, the effectors of the $\mathrm{DspA} / \mathrm{E}$ family are important for bacterial fitness or are required for pathogenicity (Fig. 1). All the proteins of this family are large, ranging from 154 (P. fluorescens) to $198 \mathrm{kDa}$ (E. amylovora and E. pyrifoliae) in size. Their sequences do not share homology to any protein of known biochemical function.

\section{DspA/E can be immunodetected associated} with the bacterial cell surface within infected plants.

In order to detect DspA/E during disease, we carried out immunolabeling with a polyclonal antibody against $\mathrm{DspA} / \mathrm{E}$ in infected apple seedlings (Gaudriault et al. 2002).

Double labeling with $\alpha$-DspA/E and $\alpha$-lipopolysaccharide (LPS) was performed on leaf tissues infiltrated with the wildtype strain CFBP1430 or with the M52 $d s p A / E$ mutant as a control. Immunolabeling with the E. amylovora LPS antibody was used to detect bacterial cells within leaf tissues, as previously described (Perino et al. 1999). The red signal obtained with LPS labeling (Fig. 2A) and the green signal obtained with DspA/E labeling (Fig. 2B) overlapped on confocal micrographs of leaf tissues infiltrated with the wild-type strain. The resulting yellow signal demonstrates colocalization of the bacterial cells and DspA/E (Fig. 2C). Transmission electron microscopy (TEM) of leaves infected with the wild-type strain confirmed a faint DspA/E-labeling associated with the bacterial 10 species, 1338 sites (1022 informative).
Maximum Parsimony ( 6101 steps required) 500 bootstrap replicates

\section{Phenotype of the mutant.}

$P$. agglomerans pv. gypsophilae.

DspE/A, 1614 aa.,

E. carotovora atroseptica

$\S, 1625$ aa.,

E. chrysanthemi.

AvrE, 1795 aa.,

$P$. syringae pv. tomato

AvrE, 1620 aa.,

P. syringae $B 728$.

RopE, 1441 aa.,

$P$. fluorescens.

§, 1702 aa. R. solanacearum.
References (accession number)
Non Pathogenic

Not tested

Non Pathogenic

Non Pathogenic

Gaudriault et al., 1997

Bogdanove et al., 1998

(CAA74156)

(AAS45452)

Frederick et al., 2001

(AAG01467)

Mor et al., 2001

(AAF76343)

Reduced virulence

(only for low inocula)

Holeva et al., 2004

(YP_050208)

Not tested

(\&)

Reduced virulence

Lorang and Keen, 1994

(AAF71499)

Not tested

(ZP_00125692)

Preston et al., 2001

(AAK74145)

Not tested
Salanoubat et al., 2002

(NP_522840)

Fig. 1. Phylogenetic tree based on aligned amino acid sequences of DspA/E homologs, using the method of maximum of parsimony. The numbers at each node are bootstrap confidence values from 500 replicates. The importance of DspA/E homologs in pathogenicity of their respective bacteria and the accession numbers of the sequences used are indicated on the right. $\S=$ Sequences that have not yet been named. $\&=$ Sequence of the DspA/E homolog from $E$. chrysanthemi 3937 obtained from the preliminary genome sequence data (funded by the United States Department of Agriculture) and annotated with the ASAP system (Glasner et al. 2003). Community-contributed annotations are made available by the University of Wisconsin and The Institute for Genomic Research. *As P. fluorescens is a nonpathogenic strain, testing the importance of the RopE protein in pathogenicity is not relevant. 
cell surface (Fig. 3B). No DspA/E labeling could be detected in plant cells, but this could simply reflect that the amount of $\mathrm{DspA} / \mathrm{E}$ in the plant cell is below the detection threshold with the technique used.
Transient expression

of $d s p A / E$ induces necrosis on apple and tobacco leaves.

To investigate whether DspA/E had an effect when delivered intracellularly, we transiently expressed $d s p A / E$ into apple

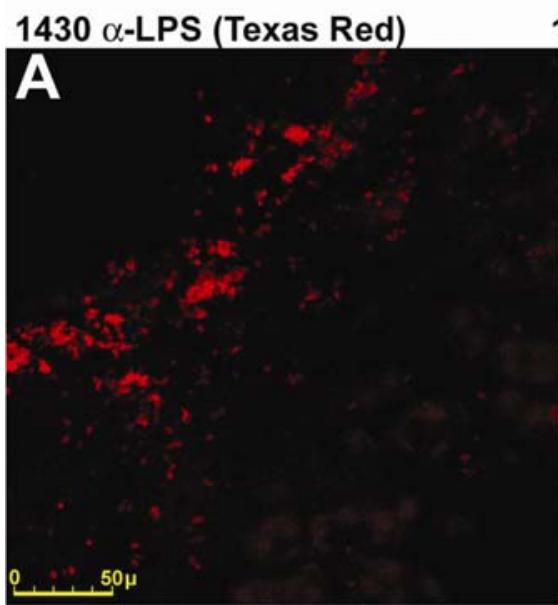

$1430 \alpha-D s p A / E(F I T C)$

$1430 \alpha-$-LPS $/ \alpha-D s p A / E(T$. Red/FITC)
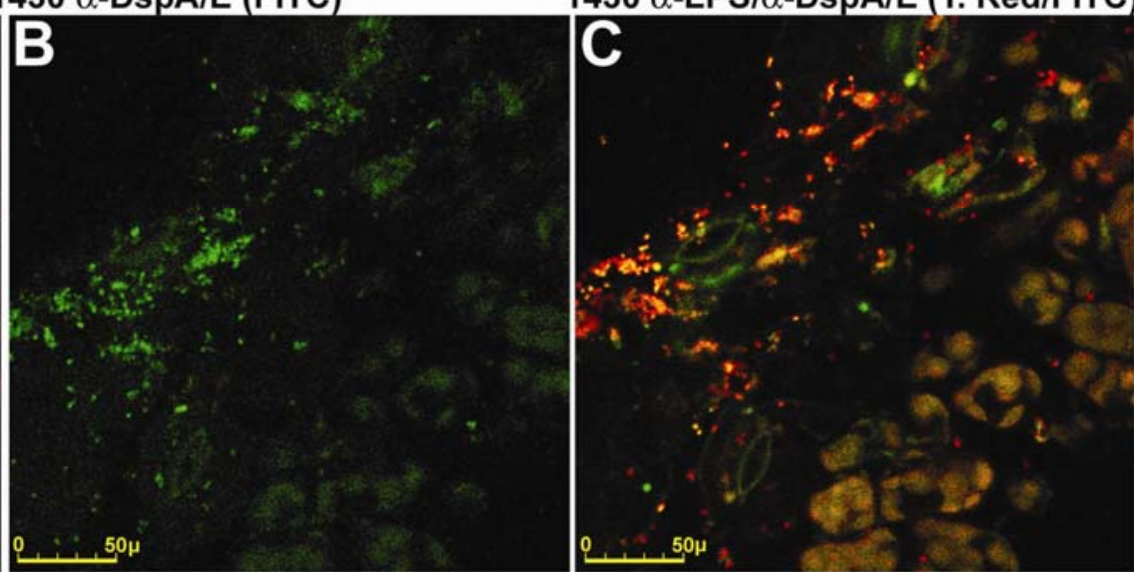

M52 $\alpha$-LPS (Texas Red) M52 $\alpha$-DspA/E (FITC)

M52 $\alpha$-LPS $/ \alpha-D s p A / E(T$. Red/FITC)
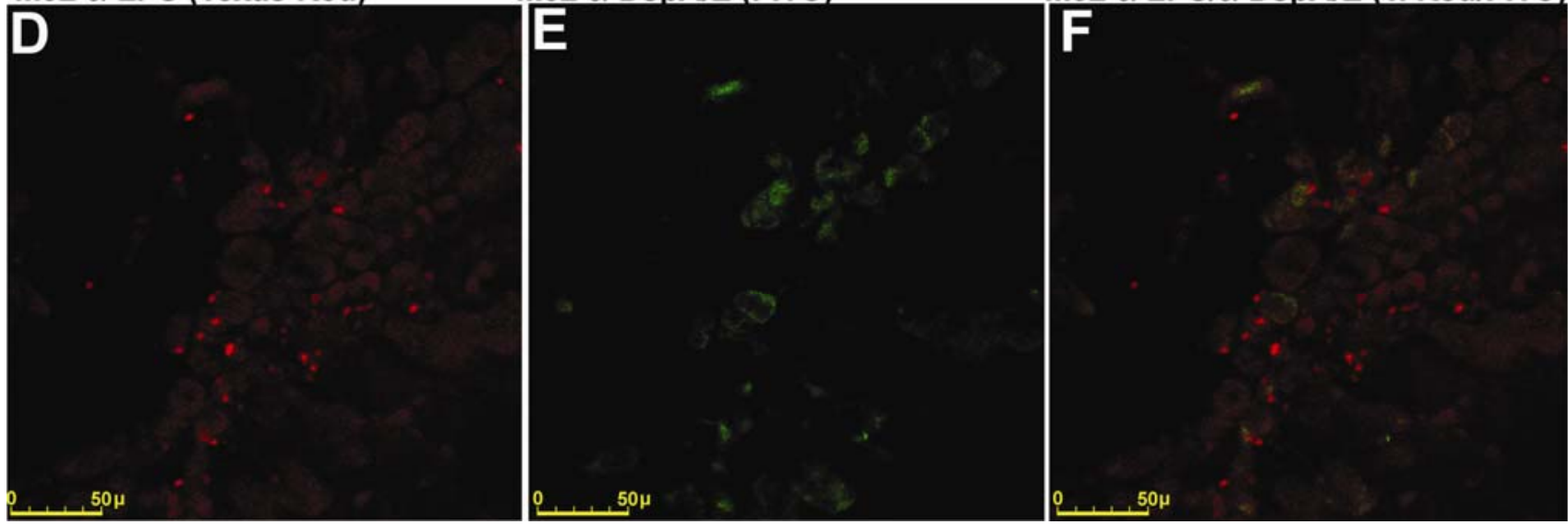

Fig. 2. Immunodetection of $\mathrm{DspA} / \mathrm{E}$ in infected leaves by confocal microscopy. Apple leaves were infiltrated with a bacterial suspension calibrated to an optical density at $600 \mathrm{~nm}$ of 2, and leaf tissues were harvested $4.5 \mathrm{hpi}$. for subsequent observation by confocal microscopy. A, B, and C, Experiments with the wild-type strain Erwinia amylovora CFBP 1430 showed that DspA/E was detected in plants (B) in association with the bacterial cells (C). D, E, and F, Control experiments with the $d s p A / E$ mutant strain M52 confirmed that no specific fluorescein isothiocyanate (FITC) immunofluorescence was detected in the absence of DspA/E (E).Texas Red immunofluorescence was used to detect lipopolysaccharides, indicating the position of bacteria in the sample (A and D). FITC immunofluorescence was used to detect DspA/E (B and E). The images obtained with Texas Red and FITC immunofluorescence were superimposed to compare staining patterns $(\mathrm{C}$ and $\mathrm{F})$.
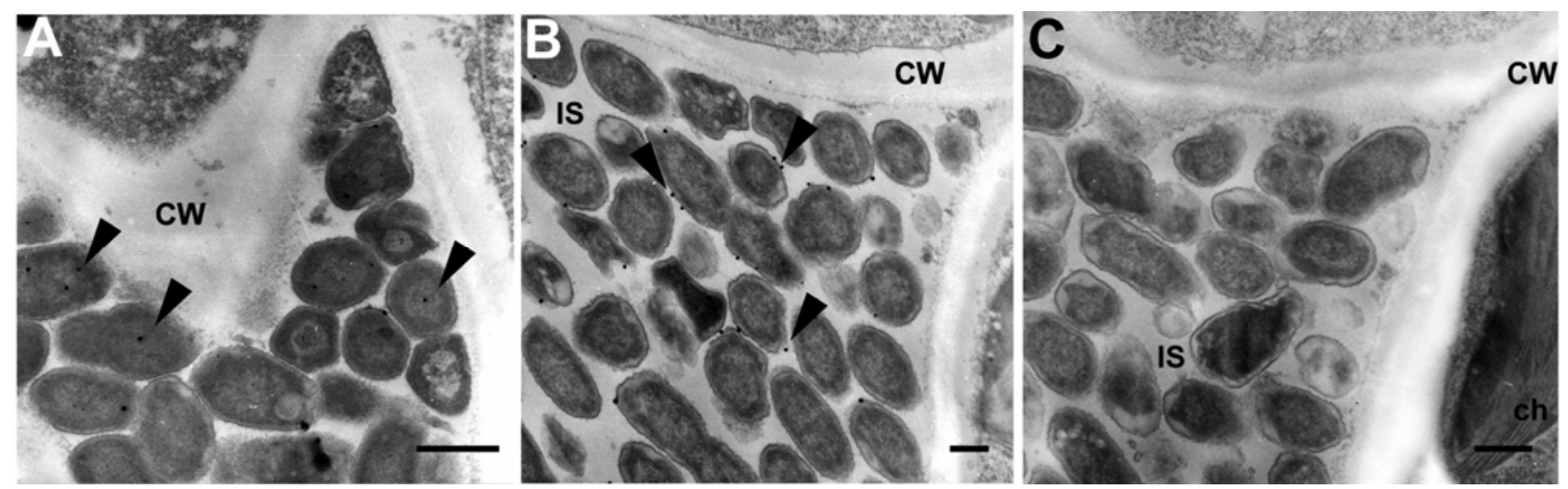

Fig. 3. Immunodetection of DspA/E at the ultrastructural level. Ultrathin transverse sections of leaves inoculated with A, the type III secretion mutant PMV6023, $\mathbf{B}$, the wild-type strain CFBP1430, or C, the $d s p A / E$ mutant strain M52. Scale bar $=1 \mu$ m. Samples were harvested 4.5 hpi for subsequent observation by transmission electron microscopy. Sections were immunogold-labeled with DspA/E antiserum. Secondary antibodies were conjugated to ultrasmall gold, and labeling was silver-enhanced using the Silver Enhancement kit (Amersham). The silver-enhanced particles were restricted to the bacterial cytoplasm in the type III secretion mutant PMV6023 (A). In wild-type strain CFBP1430, silver-enhanced particles were observed in the intercellular space (B). No silver-enhanced particles were observed in control experiments carried out with the $d s p A / E$ mutant strain M52 (C). CW = cell wall and IS = intercellular space. 
seedlings. The $d s p A / E$ gene was cloned in pBIN under the control of the cauliflower mosaic virus (CaMV) $35 \mathrm{~S}$ promoter; the resulting plasmid pAG1 was used for Agrobacterium-mediated transient expression of $d s p A / E$. As a control, transient expression of the gus reporter gene cloned under the control of the CaMV $35 \mathrm{~S}$ promoter was also performed (De Bondt et al. 1994). In the leaf area infiltrated with the CaMV 35S-gus construct, we detected $\beta$-glucuronidase activity. The weak, spotty staining observed shows that the efficiency of agroinfection in apple leaves was low. Furthermore, no macroscopic symptoms developed on apple leaves infiltrated with the CaMV 35S-gus construct, indicating that expression of the gus transgene under the control of the CaMV 35S promoter following agroinfection was not deleterious in apple leaves (Fig. 4A). In contrast, necrotic spots appeared within the infiltrated area on leaves inoculated with the CaMV 35S- $d s p A / E$ construct (Fig. 4A). Thus, DspA/E appears to induce cell death following its ectopic production in apple cells.
On tobacco leaves infiltrated with A. tumefaciens containing the CaMV 35S- $d s p A / E$ construct, necrosis developed over the entire infiltrated area within $48 \mathrm{~h}$ (Fig. 4B). The first detectable macroscopic symptom was faint glazing on the tobacco abaxial leaf surface $30 \mathrm{~h}$ after inoculation, which progressed to tissue collapse and became confluent $36 \mathrm{~h}$ postinoculation (hpi). At this timepoint (36 hpi), $\beta$-glucuronidase activity was evenly spread throughout leaves infiltrated with A. tumefaciens containing the CaMV 35S-gus construct, demonstrating a high efficiency of agroinfection in tobacco (Fig. 4B). Leaf tissues infiltrated with $A$. tumefaciens containing the CaMV 35S-gus construct yellowed slightly (Fig. 4B), due to a nonspecific response induced by $A$. tumefaciens, as previously described in similar experiments on pepper (Van den Ackerveken et al. 1996).

The high efficiency of agroinfection in tobacco allows monitoring of the response to $d s p A / E$ before the appearance of any macroscopic symptoms. Tobacco leaf tissues transiently expressing $d s p A / E$ or gus were studied under a light microscope

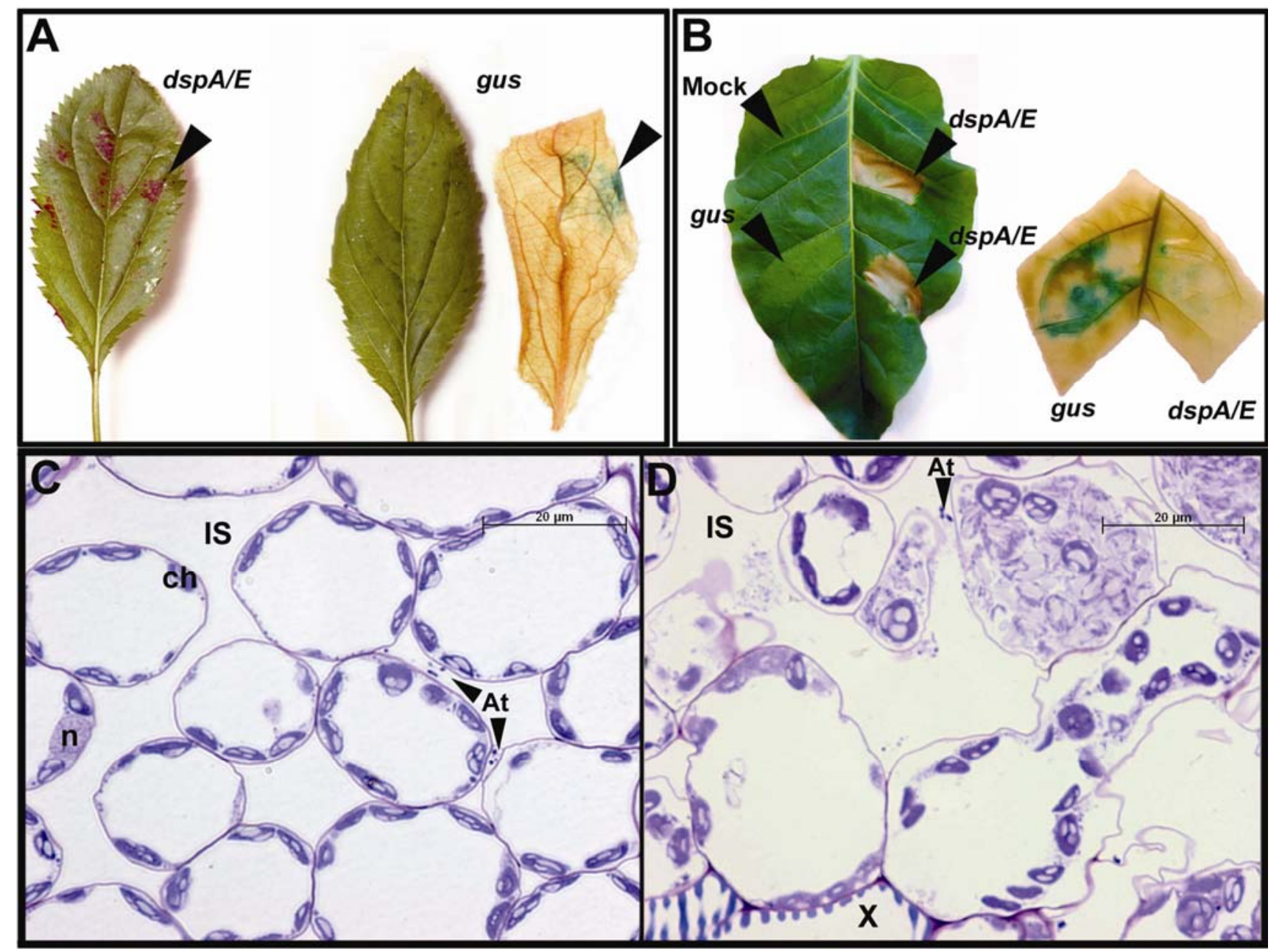

Fig. 4. Symptoms induced on host (apple) and nonhost (tobacco) plants by transient $d s p A / E$ expression. A, Apple leaves infiltrated with Agrobacterium tumefaciens EHA105 pAG1 for transient expression of $d s p A / E$; necrotic spots developed in the infiltrated area two days after inoculation. These spots gradually increased in number until seven days after inoculation. As a control, apple leaves infiltrated with EHA 101 pFAJ3000, for transient expression of the gus reporter gene, did not develop necrotic symptoms. Only few spots on the leaf displayed the typical blue staining characteristic of $\beta$-glucuronidase activity, indicating that agroinfection was not very efficient in apple. These blue spots appeared on the leaves agroinfected with gus over the same time scale as the necrotic spots appeared on the leaves agroinfected with $d s p A / E$. B, Tobacco leaves infiltrated with A. tumefaciens EHA105 pAG1 (DspA/E; D), A. tumefaciens EHA101 pFAJ3000 (Gus; G), and mock-infiltrated (M). Necrosis of the whole area agroinfected with EHA105 pAG1 is observed 48 hpi, with the first macroscopic symptoms appearing at 30 hpi. $\beta$-glucuronidase activity in tissues infected with EHA101 pFAJ3000 showed agroinfection to be highly efficient in tobacco, as the blue staining appeared in most of the infiltrated area. C, Topographical staining with toluidin blue of a section of tobacco leaf infiltrated with EHA101 pFAJ3000, $24 \mathrm{~h}$ after agroinfiltration. The shape of cells is well conserved, organites are pressed against the cell wall by intact vacuoles, and the staining of cell walls is well contrasted, demonstrating that tissues are healthy. D, Topographical staining with toluidine blue of a section of tobacco leaf infiltrated with EHA105 pAG1, $24 \mathrm{~h}$ after agroinfiltration. Cells are disorganized, with more organites loose in the cytoplasm than in panel C, and cell walls are swollen. $\mathrm{IS}=$ intercellular space, $\mathrm{At}=$ A. tumefaciens cells, $\mathrm{ch}=$ chloroplast, $\mathrm{n}=$ nucleus, and $\mathrm{X}=\mathrm{xylem}$. 
to determine whether a phenotype in terms of response to DspA/E could be detected less than $30 \mathrm{~h}$ after inoculation. Topographic staining with toluidine blue revealed a clear collapse of the mesophyll cells, disorganized nuclei, and swelling of the plant cell wall $24 \mathrm{~h}$ after inoculation, in response to the transient expression of $d s p A / E$ (Fig. 4D). No such response was observed following the transient expression of gus (Fig. 4C). In some cases, the plant cell wall was found to have swollen in response to transient expression of $d s p A / E 18 \mathrm{~h}$ after inoculation, suggesting that the disorganization of cell structures had already begun $18 \mathrm{hpi}$

We tried to determine exactly when transient expression began by i) using immunocytochemistry and microscopy to visualize the appearance of $\mathrm{DspA} / \mathrm{E}$ and ii) amplifying the $d s p A / E$ transcript by reverse transcriptase-polymerase chain reaction (PCR) (from both the 5' and 3' ends of the transcript) from the A. tumefaciens-infected tissues. We were unable to visualize the protein or its transcript, suggesting that $d s p A / E$ mRNA and protein are rapidly degraded during transient expression (data not shown).

Altogether, results show that transient expression of $d s p A / E$ induced a necrosis both on apple seedlings and tobacco leaves, although the agroinfection was less efficient in apple seedlings
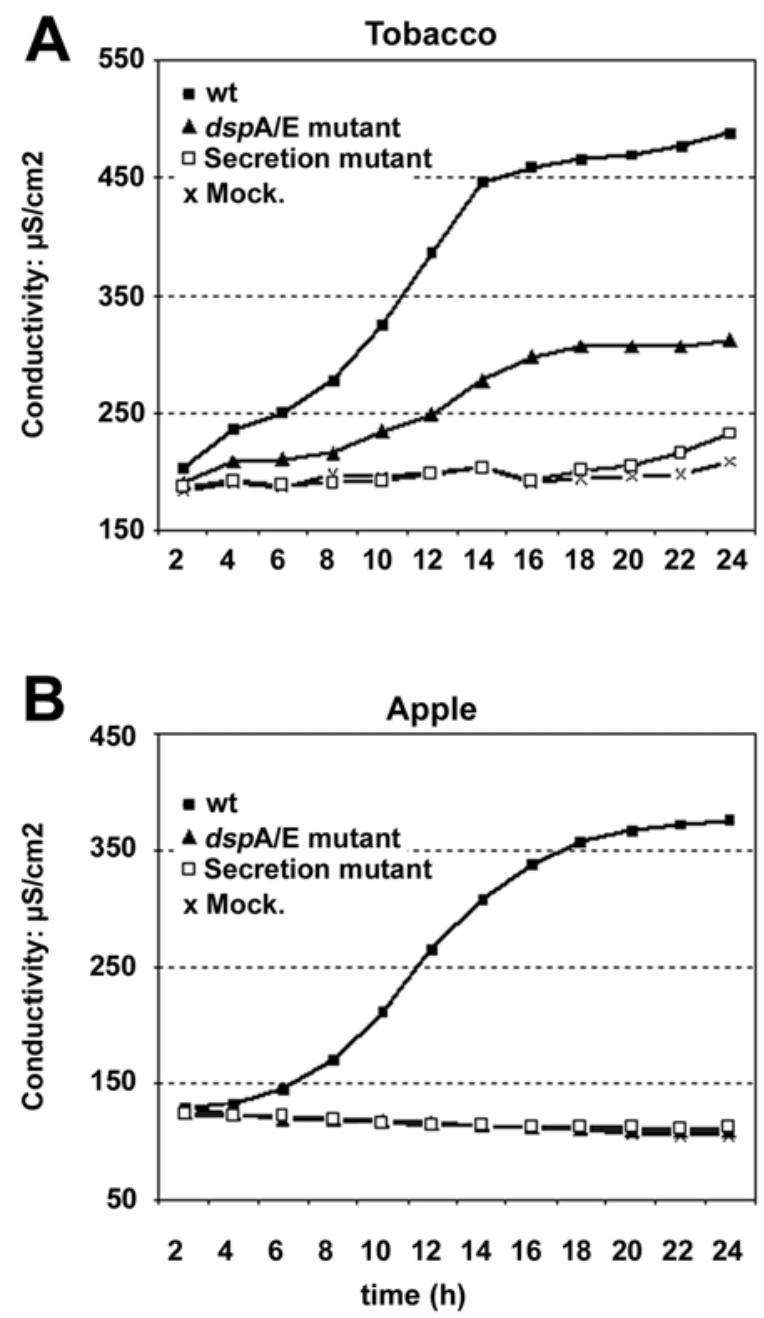

Fig. 5. Monitoring of electrolyte leakage in apple and tobacco leaf disks. Electrolyte leakage was measured every $2 \mathrm{~h}$ on leaf disks infiltrated with bacterial suspensions at a density of $10^{9} \mathrm{CFU} \mathrm{ml^{-1 }}$. $=E$. amylovora CFBP1430 (wild-type strain), $\boldsymbol{\Delta}=E$. amylovora M52 $d s p A / E$ mutant strain, $\square=$ E. amylovora PMV6023 type III secretion mutant strain, and $\mathrm{x}=$ mock infection. Experiments were performed on $\mathbf{A}$, tobacco and $\mathbf{B}$, apple leaf disks. than in tobacco leaves. It seems likely that very little DspA/E is required to induce necrosis, because neither the protein nor the mRNA were detected, despite use of the CaMV 35S promoter to drive $d s p A / E$ expression.

\section{DspA/E induces electrolyte leakage \\ in apple and tobacco plants.}

We found that $d s p A / E$ induced necrosis when ectopically expressed in tobacco. However, a mutant $d s p A / E$ strain has also been shown to induce a HR in tobacco (Barny et al. 1990). To assess the importance of DspA/E for cell death, we compared the electrolyte leakage induced in tobacco and apple leaves in response to inoculation with the $E$. amylovora wild-type strain CFPB1430, the $d s p A / E$ mutant M52, and the type III secretion mutant PMV6023.

Inoculation with wild-type strain CFBP1430 led to a significant increase in electrolyte leakage in both host and nonhost plants. The increase began 4 hpi and was exponential until 16 hpi, when a plateau was reached (Fig. 5). The leakage observed in both apple and tobacco was dependent on type III secreted or injected proteins, as no significant increase in electrolyte leakage was recorded in the secretion mutant strain PMV6023 (Fig. 5).

In apple, $d s p A / E$ mutant strain M52 induced no significant increase in ion leakage (Fig. 5B). Thus, in apple, the increase in electrolyte leakage is dependent on DspA/E. This is consistent with the absence of symptom induction by $d s p A / E$ mutants in apple plants (Barny et al. 1990; Gaudriault et al. 1997).

The electrolyte leakage elicited by the $d s p A / E$ mutant strain M52 was only one third that induced by the wild-type strain CFBP1430 (Fig. 5A). DspA/E, therefore, plays a major role in inducing cell death during interactions between $E$. amylovora and the nonhost plant tobacco. The residual electrolyte leakage observed may be attributable to other type III secreted proteins, including harpins, which are known to induce HR efficiently in tobacco (Gaudriault et al. 1998; Kim and Beer 1998; Wei et al. $1992)$. This is consistent with the observation that $d s p A / E$ mutants trigger a HR in tobacco (Barny et al. 1990).

Altogether, our electrolyte leakage data indicate that DspA/E is a major cell-death inducer in both tobacco and apple.

\section{Transient expression of $d \operatorname{spA} / E$}

inside tobacco leaves leads to delayed expression of PR1.

We monitored the pattern of expression of the classical defense marker PRl during the transient expression of gus or $d s p A / E$ in tobacco leaves. Surprisingly, $P R I$ expression was stronger and occurred earlier in leaf tissues inoculated with $A$. tumefaciens containing the CaMV 35S-gus construct than in leaf tissues inoculated with A. tumefaciens containing the CaMV 35S- $d s p A / E$ construct (Fig. 6). In leaf tissues transiently expressing gus, PRI expression was clearly detected 24

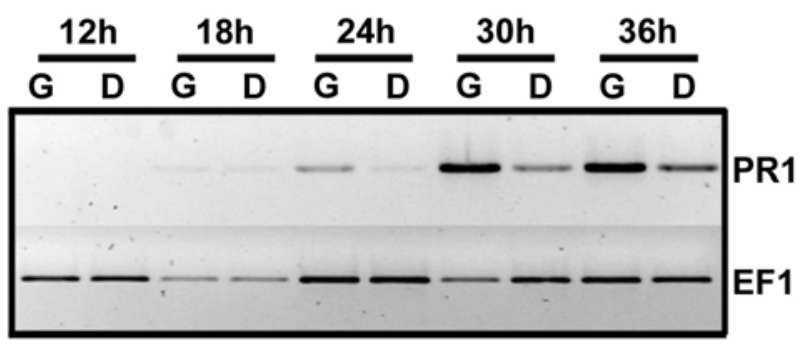

Fig. 6. Transient expression of $d s p A / E$ delays $P R 1$ expression in tobacco. Semiquantitative reverse transcription-polymerase chain reaction was performed on mRNAs isolated from plant tissues transiently expressing gus (G) or $d s p A / E$ (D) $12 \mathrm{~h}, 18 \mathrm{~h}, 24 \mathrm{~h}, 30 \mathrm{~h}$, and $36 \mathrm{~h}$ after agroinfiltration. EF1 was used as a loading control. 
hpi and was maximal 30 and 36 hpi. In leaf tissues transiently expressing $d s p A / E, P R 1$ expression was clearly detectable only after $30 \mathrm{hpi}$; the signal was stronger at $36 \mathrm{hpi}$ but, nevertheless, remained weaker than that recorded in gus-expressing tissues (Fig 6). Similar results were obtained in three independent experiments on different plants. Thus, the transient expression of $d s p A / E$ delays $P R I$ expression in tobacco.

\section{DISCUSSION}

In the present paper, we show that we could detect $\mathrm{DspA} / \mathrm{E}$ associated with the bacterial cell surface in the intercellular spaces of apple leaves. However, we have been unable to detect DspA/E in plant cells. This could reflect technical limitations or biological reasons, as DspA/E could be masked in a multicomponent protein complex once inside the plant cell or could be degraded and processed very rapidly within plant cells.

Although the electron microscopy studies gave inconclusive results, the target of $\mathrm{DspA} / \mathrm{E}$ is probably located inside the plant cell, since DspA/E induces necrotic symptoms once artificially delivered into apple plant cells via agroinfection. Thus, during disease development, DspA/E is probably injected via the TTSS and induces cell death alone, without the assistance of other bacterial effectors. The necrosis observed following agroinfection of $d s p A / E$ is particularly interesting because it mimics the main disease symptoms elicited by E. amylovora. The involvement of DspA/E in cell death was confirmed by electrolyte leakage measurements, as a $d s p A / E$ mutant was unable to induce electrolyte leakage in apple plants. As the $d s p A / E$ mutant is not pathogenic and cannot grow in planta (Barny et al. 1990), E. amylovora appears to be dependent on DspA/Emediated cell death for disease development. Such a behavior differs from that of $P$. syringae, which deploys many different TTSS effectors to suppress cell death. In that sense, E. amylovora behaves as a model bacterial necrotrophic pathogen.

$\mathrm{DspA} / \mathrm{E}$ belongs to a family of conserved bacterial effectors found in many plant pathogenic bacteria. The genes encoding these effectors are located in the conserved effector locus next to the type III secretion cluster (Alfano et al. 2000). Functional cross-complementation between $d s p A / E$ and its $P$. syringae homolog avrE has been previously demonstrated (Bogdanove et al. 1998), suggesting that DspA/E homologs have similar basic roles to DspA/E during disease. However the importance of each homolog during disease development depends on the bacteria concerned. For example, mutations in $w t s E$ and $d s p E-$ the $d s p A / E$ homologs of Pantoea stewartii and Pantoea agglomerans pv. gypsophilae-lead to major change in virulence (Frederick et al. 2001; Mor et al. 2001). In contrast, mutations in the DspA/E homolog of Erwinia carotovora subsp. atroseptica, the pathogenicity of which depends mainly on cell-walldegrading enzymes secreted through the TTSS (Thomson et al.
1999), was found to affect virulence only if very low levels of bacterial inoculum were used (Holeva et al. 2004). Similarly, the AvrE mutant of $P$. syringae pv. tomato is pathogenic but generates much less severe symptoms and displays lower rate of growth than the wild-type strain in tomato leaves (Lorang et al. 1994). This phenotype may be explained by the extensive redundancy of the type III effectors secreted by $P$. syringae (Collmer et al. 2002; Greenberg and Vinatzer 2003). For example, $P$. syringae pv. tomato DC3000 uses at least two different type III effectors, HopPtoM and the DspA/E homolog AvrE, to induce necrosis in its host plant (DebRoy et al. 2004).

Agroinfection of $d s p A / E$ induced necrosis on nonhost tobacco plants. This raises the question as to whether the necrosis elicited on nonhost tobacco plants results from the same biological process as the necrosis observed in host apple plants or whether tobacco contains a major $R$ gene recognizing DspA/E and eliciting a HR. Indeed, nonhost $R$ genes have been identified in interactions between Pseudomonas spp. or Xanthomonas spp. and plants (Simonich and Innes 1995; Warren et al. 1999; Zhao et al. 2004). However, it is generally accepted that the development of a hypersensitive reaction and disease necrosis in response to these pathogens must be considered as similar processes progressing with different timings (Klement 1982; Lamb et al. 1992; Tao et al. 2003). Several studies conducted with Pseudomonas spp. suggested that R proteins accelerate overall defense responses whereas many type III effectors act as suppressors of plant cell death and delay plant defense reactions (Bretz et al. 2003; Chang et al. 2004; Espinosa et al. 2003; Jackson et al. 1999; Jamir et al. 2004; Lopez-Solanilla et al. 2004; Tsiamis et al. 2000). The situation is quite different with E. amylovora-plant interactions, because the timing of the local necrosis induced on host and nonhost plants is similar. Both reactions were mediated by a sustained production of superoxide anion, lipid peroxidation, electrolyte leakage, and concomitant increases in the level of several antioxidant enzymes (ascorbate peroxidases, gluthatione reductases, glutathion- $S$-transferases, and peroxidases) at similar rates and over similar timecourses (Venisse et al. 2001). These local necrotic reactions were heavily dependent on $d s p A / E$ expression, because the electrolyte leakage induced in both plants by a $d s p A / E$ mutant was much less severe than that induced by the wild-type strain. This suggests that DspA/E mediated the same basic attack mechanism in host and nonhost plants.

In tobacco, $P R I$ was expressed later in plants infiltrated with $A$. tumefaciens containing $d s p A / E$ than in plants infiltrated with A. tumefaciens containing gus. This suggests that DspA/E-mediated necrosis may be associated with the inhibition of plant defense response. This recalls the action of the DspA/E homolog AvrE, which was recently involved in suppression of salicylic acid-dependent callose deposition during disease in Arabidopsis thaliana (DebRoy et al. 2004) and, once again, suggests that both proteins have the same basic role.

Table 1. List of strains and plasmids used in this study

\begin{tabular}{lll}
\hline Strain or plasmid & \multicolumn{1}{c}{ Characteristics $^{\mathbf{a}}$} & Reference \\
\hline Erwinia amylovora & Wild-type strain & Paulin and Samson 1973 \\
CFBP1430 & CFBP1430 hrcV::MuPR13 & Barny et al. 1990 \\
PMV6023 & CFPB1430 dspA/E::uidA Km ${ }^{\mathrm{r}}$ & Gaudriault et al.1997 \\
M52 & Strain with high transformation efficiency & Hood et al. 1986 \\
Agrobacterium tumefaciens & Strep derivative of EHA101 & Hood et al. 1993 \\
EHA 101 & gus gene cloned in pBIN under the control of the CaMV 35S promoter & De Bondt et al. 1996 \\
EHA105 & 8.0-kb HindIII to PstI fragment of the $d s p$ region cloned into pT7-6 & Gaudriault et al. 1997 \\
pFAJ3000 & $d s p A / E$ gene cloned in pBIN under the control of the CaMV 35S promoter & This study \\
pMAB79 & $d s p A / E$ gene cloned into pUC19 & This study \\
pAG1 & \\
pTB4
\end{tabular}

\footnotetext{
${ }^{\mathrm{a}} \mathrm{Km}^{\mathrm{r}}$ and $\mathrm{Strep}^{\mathrm{r}}$ indicate kanamycin or streptomycin resistant; CaMV = Cauliflower mosaic virus
} 
It was previously shown that $\mathrm{DspA} / \mathrm{E}$ plays a major role in the induction of oxidative stress in planta (Venisse et al. 2003). Here, we show that DspA/E is a major inducer of cell death. How DspA/E achieves its goal remains unknown. Future work aims to identify molecules interacting with $\mathrm{DspA} / \mathrm{E}$ in plants and to identify DspA/E biochemical function.

\section{MATERIALS AND METHODS}

\section{Bacterial strains and culture conditions.}

Bacterial strains and plasmids are listed in Table 1 or in the text. Luria-Bertani broth (LB) medium was routinely used for bacterial growth. When necessary, the following antibiotics were added to the medium ( $\mu \mathrm{g} \mathrm{ml}^{-1}$ ): ampicillin (Ap), 100; kanamycin $(\mathrm{Km}), 50$; and chloramphenicol, 20.

\section{Cloning of $d s p A / E$ into pBIN and pUC19.}

The full-length $d s p A / E$ gene was amplified by PCR with the Roche expand high fidelity system, using pMAB79 as a template (Gaudriault et al. 1997). For amplification, PCR conditions were as follows: $94^{\circ} \mathrm{C}$ for $2 \mathrm{~min}$, followed by 15 cycles of $94^{\circ} \mathrm{C}$ for $10 \mathrm{~s}, 48^{\circ} \mathrm{C}$ for $30 \mathrm{~s}, 68^{\circ} \mathrm{C}$ for $4 \mathrm{~min}$ and 10 cycles of $94^{\circ} \mathrm{C}$ for $10 \mathrm{~s}, 48^{\circ} \mathrm{C}$ for $30 \mathrm{~s}, 68^{\circ} \mathrm{C}$ for $4 \mathrm{~min}$ in the first cycle and increasing by $20 \mathrm{~s}$ in each subsequent cycle. Primers for the amplification of $d s p A / E$ were designed based on the Y13831 sequence. An $X b a$ I restriction site was inserted in the forward primer and a SacI site in the reverse primer to facilitate subsequent cloning. The sequence of the primers used were as follows (restriction sites are shown in bold): $d s p A / E$ $X b a \mathrm{I}$ 5'-GCTCTAGAATGGAATTAAAATCAC-3', and $d s p A / E$ -SacI 5'-CGCGAGCTCTTAGCTCTTCATTTC-3'.

PCR products were cloned into pGEM-T Easy (Promega, Charbonnières-les-bains, France) and were used to transform Escherichia coli DH5- $\alpha$. We checked that the insert was present in putative transformants, by restriction analysis with $X b a \mathrm{I}$ and SacI of plasmid DNA isolated from the positive clones (white colonies, $\mathrm{Ap}^{\mathrm{r}}$ ).

To subclone the PCR-amplified $d s p A / E$ into $\mathrm{pBIN}$, a vector suitable for transient expression experiments, the pGEM$d s p \mathrm{~A} / \mathrm{E}$ and pBIN-mGFP4 (Haseloff et al. 1997) were digested with $X b a \mathrm{I}$ and $S a c \mathrm{I}$. Restriction products were bulked and ligated using standard procedures. Ligation products were introduced into Escherichia coli DH5- $\alpha$ and $\mathrm{Km}^{\mathrm{r}} / \mathrm{Ap}^{\mathrm{s}}$ transformants were selected on LB containing Km (pBIN). Positive clones were identified by PCR on DNA from colonies. The pBIN derivative containing full-length $d s p A / E$ under the control of the CAMV35S promoter was called pAG1. The full-length $d s p A / E$ gene was then extracted from pAG1 and inserted into pUC19, a vector suitable for expression in bacteria; pAG1 and pUC19 were digested with $X b a \mathrm{I}$ and $S a c \mathrm{I}$. Restriction products were bulked and ligated using standard procedures. Positive $\mathrm{Ap}^{\mathrm{r}}$ clones were identified by restriction analysis with $X b a \mathrm{I}$ and SacI. The plasmid obtained was named pTB4. In pTB4, the expression of $d s p A / E$ is driven by the lac promoter. We used pAG1 to electroporate the EHA105 strain of A. tumefaciens (Hood et al. 1993), and pTB4 was used to electroporate the $E$. amylovora $d s p A / E$ mutant M52 (Gaudriault et al. 1997). We demonstrated that the PCR-amplified copy of $d s p A / E$ encoded a functional DspA/E protein by showing pTB4 restored the pathogenicity of the $d s p A / E$ mutants M52 in host plants.

\section{Plant material and inoculum preparation.}

Pathogenicity and electrolyte leakage assays. Apple seedlings were inoculated with strains CFBP1430, M52, and M52 (pTB4). Inoculum was prepared and inoculation was carried out as previously described (Perino et al. 1999). Appearance of fire blight symptoms was monitored over seven days. Electro- lyte leakage was determined in apple and tobacco on leaf disks, as previously described (Gaudriault et al. 1998).

Transient expression experiments. Bacterial inocula were prepared as follows. A. tumefaciens EHA101 pFAJ3000 (gus) and EHA105 pAG1 $(d s p A / E)$ strains were resuspended in Murashige-Skoog broth and their optical density (OD) was adjusted to an $\mathrm{OD}_{600}$ of 0.5 .

Apple seedlings. Three-week-old 'Golden Delicious' apple seedlings were used. Prior to inoculation, seedlings were maintained in conditions of $100 \%$ humidity for $24 \mathrm{~h}$ to maximize stomatal opening. Each seedling was infiltrated with $A$. tumefaciens EHA101 pFAJ3000 (gus) or EHA105 pAG1 $(d s p A / E)$ under vacuum. Infiltrations were carried out on five of the uppermost leaves on the plant. The phenotype of the treated leaves was monitored for 7 days after inoculation.

Tobacco plants. Plants of Nicotiana tabacum cv. xanthi were grown in the greenhouse until they had 12 to 14 leaves. Leaves were perforated with a needle at the site of inoculation. Bacterial suspensions were then infiltrated into the leaf using a needleless syringe. After infiltration, we monitored the phenotype of the infected leaves for at least $48 \mathrm{~h}$.

\section{Determination of $\boldsymbol{\beta}$-glucuronidase activity.}

$\beta$-glucuronidase activity was detected by infiltrating leaves with $4 \mathrm{mM}$ potassium ferricyanide $\left(\mathrm{K}_{3} \mathrm{Fe}(\mathrm{CN})_{6}\right), 0.05 \mathrm{mM}$ potassium ferrocyanide $\left(\mathrm{K}_{4} \mathrm{Fe}(\mathrm{CN})_{6} \cdot 3 \mathrm{H}_{2} \mathrm{O}\right), 10 \mathrm{mM}$ EDTA, 20 $\mathrm{mM} \mathrm{NaH} \mathrm{PO}_{4}, 30 \mathrm{mM} \mathrm{Na} \mathrm{HPO}_{4}, 3 \mathrm{mM} \mathrm{X}$-gluc. Leaves were then incubated overnight at $37^{\circ} \mathrm{C}$. Leaf pigments were removed by immersing the leaves several times in $90 \%$ ethanol.

\section{Microscopic observations.}

Immunolocalization of $D s p A / E$. Bacteria were grown in LB medium at $30^{\circ} \mathrm{C}$ up to an $\mathrm{OD}_{600}$ of 2 , prior to inoculation. In these growth conditions, the E. amylovora TTSS is not induced and DspA/E is not secreted (Gaudriault et al. 1997). Infected leaf tissues were harvested $4.5 \mathrm{~h}$ after inoculation-a time sufficient to allow induction of the TTSS (Boureau et al. 2002) - and were infiltrated with $3 \%$ paraformaldehyde, $1 \%$ glutaraldehyde in $0.1 \mathrm{M}$ cacodylate buffer, $\mathrm{pH} 7.2$, under vacuum. Samples were then incubated at room temperature for $3 \mathrm{~h}$, were washed four times in phosphate buffered saline (PBS; $1.9 \mathrm{mM} \mathrm{KH}_{2} \mathrm{PO}_{4}$, $8.1 \mathrm{mM} \mathrm{Na}_{2} \mathrm{HPO}_{4}$, and $150 \mathrm{mM} \mathrm{NaCl}$ at $\mathrm{pH} 7.4$ ), were handsectioned with a razor blade, were incubated in permeabilization and blocking buffer $(0.5 \%$ bovine serum albumin [BSA], $40 \%$ fish gelatin, $0.15 \%$ glycine, 1:1,000 (vol/vol) Tween 20, 3.3\% goat serum in PBS) for $30 \mathrm{~min}$, and then, were incubated overnight at $4{ }^{\circ} \mathrm{C}$ with $\alpha$-DspA/E rabbit antibody or $\alpha$-LPS rabbit antibody, diluted 1:500 and 1:12,000, respectively, in PBS-T (PBS $+1: 1,000$ Tween-20 $+0.02 \%$ sodium azide). Samples were washed four times for $10 \mathrm{~min}$ each in PBS buffer and were incubated for $2 \mathrm{~h}$ at room temperature, with the secondary antibody diluted 1:20 in blocking buffer II (5 g of BSA per liter + $0.1 \%$ fish gelatin $+3.3 \%$ rabbit serum $+0.15 \%$ glycine + 1:12,000 Tween-20 in PBS). Samples were then washed twice for $10 \mathrm{~min}$ each in sterile distilled water.

For confocal microscopy, we used single labeling (DspA/E or LPS antibody) and double labeling (DspA/E and LPS antibodies). Secondary antibodies were conjugated to fluorescein isothiocyanate for DspA/E detection and to Texas Red for LPS detection, and samples were mounted in VectaShield for confocal microscopy.

For electron microscopy, only single labeling experiments were carried out, using a DspA/E polyclonal antibody. Secondary antibodies were conjugated to ultrasmall gold, and labeling was silver-enhanced using the Silver Enhancement kit (Amersham Biosciences Europe, Orsay, France). Samples were then washed twice for $10 \mathrm{~min}$ each in sterile distilled water. 
Samples were contrast-stained by incubation in $1 \%$ uranyl acetate for $75 \mathrm{~min}$. Samples were again washed twice for $10 \mathrm{~min}$ each in sterile distilled water, were dehydrated by incubation in $70 \%$ ethanol for two days, and were embedded in EpoxyAraldite resin (FLUKA, Sigma-Aldrich, St. Quentin, Flavier, France). We observed $0.1-\mu \mathrm{m}$ sections by TEM.

\section{Topographic staining.}

Tobacco leaf tissues were sampled from areas infiltrated with A. tumefaciens EHA105 pAG1 and EHA101 pFAJ3000 18 and $24 \mathrm{hpi}$, and were fixed, embedded in resin, sectioned, and stained with toluidine blue, as previously described (Perino et al. 1999). Observations were made on three independent samples. In each sample, 20 fields were observed and comparisons were made at each timepoint in blind tests for the 60 fields obtained in each set of conditions.

\section{PCR.}

Agroinfiltrated areas of tobacco leaves were crushed into fine powder in liquid nitrogen. Proteinase $\mathrm{K}$ lysis and total RNA extraction with phenol/chloroform were carried out using standard procedures ( $\mathrm{LiCl}$ precipitation; Sambrook et al. 1989). Total RNA extracts were quantified by spectrophotometry, and their quality was checked on agarose gel. Isolation of mRNA was then carried out on $75 \mu \mathrm{g}$ of total RNA, using the PolyATtract kit (Promega). Isolated mRNAs were resuspended in $50 \mu \mathrm{l}$ of sterile distilled water and were stored at $-80^{\circ} \mathrm{C}$ until further use. Isolated mRNAs $(5 \mu \mathrm{l})$ were used for first-strand cDNA synthesis. Reverse transcription was performed with MMLV reverse transcriptase (RNase H Minus, Point Mutant; Promega), using the protocols for cDNA synthesis described in the Universal RiboClone cDNA synthesis system (Promega). Second-strand cDNAs were obtained using conditions described in the Universal RiboClone cDNA synthesis system (Promega) and were resuspended in $30 \mu \mathrm{l}$ of sterile distilled water.

PCR was carried out on double-stranded cDNAs generated from mRNA as described above. We used the following PCR amplification program: $94^{\circ} \mathrm{C}$ for $5 \mathrm{~min}$, cycles of $94^{\circ} \mathrm{C}, 1 \mathrm{~min}$; $52^{\circ} \mathrm{C}, 1 \mathrm{~min} ; 72^{\circ} \mathrm{C}, 1 \mathrm{~min}$, followed by a final incubation for 1 min at $72^{\circ} \mathrm{C}$. $E F 1$ was amplifed over 25 cycles, using primers based on the AF120093 sequence (forward: 5'-CCTTGTGGA AGTTTGAGACCACC-3' and reverse: 5'-CCAGTTTCCACA CGACCAACAG-3'). PR1 was amplified over 26 cycles, using primers based on the \#X12737 sequence (forward: 5'-GTAGA ACCTTTGACCTGGGACG-3' and reverse: 5'-GACCACTTG GTCTTTTTATAGATCC-3').

\section{ACKNOWLEDGMENTS}

We gratefully thank D. Expert, M. Fagard, J. P. Paulin, J. Pedron, and D. Reis for their critical reading of the manuscript and useful discussions. We also thank E. Chevreau for assistance with apple transformation, C. Roux for assistance with microscopy, J. Franchel for assistance with figure editing, and S. Gaubert for technical assistance. N. T. Perna is thanked for making available the $d s p \mathrm{E}$ sequence of E. chrysanthemi from the preliminary genome data. H. ElMaarouf-Bouteau and T. Boureau were funded by postdoctoral and doctoral grants, respectively.

\section{LITERATURE CITED}

Alfano, J. R., Charkowski, A. O., Deng, W. L., Badel, J. L., PetnickiOcwieja, T., van Dijk, K., and Collmer, A. 2000. The Pseudomonas syringae Hrp pathogenicity island has a tripartite mosaic structure composed of a cluster of type III secretion genes bounded by exchangeable effector and conserved effector loci that contribute to parasitic fitness and pathogenicity in plants. Proc. Natl. Acad. Sci. U.S.A. 97:4856-4861.

Alfano, J. R., and Collmer, A. 2004. Type III secretion system effector proteins: Double agents in bacterial disease and plant defense. Annu. Rev. Phytopathol. 42:385-414.
Barny, M. A., Guinebretière, M. H., Marcais, B., Coissac, E., Paulin, J. P., and Laurent, J. 1990. Cloning of a large gene cluster involved in Erwinia amylovora CFBP1430 virulence. Mol. Microbiol. 4:777-786.

Bogdanove, A. J., Kim, J. F., Wei, Z., Kolchinsky, P., Charkowski, A. O. Collmer, A., and D. W., Beer, S. V. 1998. Homology and functional similarity of an hrp-linked pathogenicity locus, $d s p \mathrm{EF}$, of Erwinia amylovora and the avirulence locus avrE of Pseudomonas syringae pv. tomato. Proc. Natl. Acad. Sci. U.S.A. 95:1325-1330.

Boureau, T., Routtu, J., Roine, E., Taira, S., and Romantschuk, M. 2002. Localization of hrpA-induced Pseudomonas syringae pv. tomato DC3000 in infected tomato leaves. Mol. Plant. Pathol. 3:451-460

Bretz, J. R., Mock, N. M., Charity, J. C., Zeyad, S., Baker, C. J., and Hutcheson, S. W. 2003. A translocated protein tyrosine phosphatase of Pseudomonas syringae pv. tomato DC3000 modulates plant defence response to infection. Mol. Microbiol. 49:389-400.

Chang, J. H., Goel, A. K., Grant, S. R., and Dangl, J. L. 2004. Wake of the flood: Ascribing functions to the wave of type III effector proteins of phytopathogenic bacteria. Curr. Opin. Microbiol. 7:11-18.

Collmer, A., Lindeberg, M., Petnicki-Ocwieja, T., Schneider, D. J., and Alfano, J. R. 2002. Genomic mining type III secretion system effectors in Pseudomonas syringae yields new picks for all TTSS prospectors. Trends Microbiol. 10:462-469.

Cornelis, G. R., and Van Gijsegem, F. 2000. Assembly and function of type III secretory systems. Annu. Rev. Microbiol. 54:735-774.

De Bondt, A., Eggermont, K., Druart, P., De Vil, M., Goderis, I., Vanderleyden, J., and Broekaert, W. 1994. Agrobacterium-mediated transformation of apple (Malus $\times$ domestica Borkh.): An assessment of factors affecting gene transfer efficiency during early transformation steps. Plant Cell Rep. 13:587-593

DebRoy, S., Thilmony, R., Kwack, Y. B., Nomura, K., and He, S. Y. 2004. A family of conserved bacterial effectors inhibits salicylic acid-mediated basal immunity and promotes disease necrosis in plants. Proc. Natl. Acad. Sci. U.S.A. 101:9927-9932.

Espinosa, A., Guo, M., Tam, V. C., Fu, Z. Q., and Alfano, J. R. 2003. The Pseudomonas syringae type III-secreted protein HopPtoD2 possesses protein tyrosine phosphatase activity and suppresses programmed cell death in plants. Mol. Microbiol. 49:377-387.

Frederick, R. D., Ahmad, M., Majerczak, D. R., Arroyo-Rodriguez, A. S., Manulis, S., and Coplin, D. L. 2001. Genetic organization of the Pantoea stewartii subsp. stewartii hrp gene cluster and sequence analysis of the $h r p \mathrm{~A}, h r p \mathrm{C}, h r p \mathrm{~N}$, and $w t s \mathrm{E}$ operons. Mol. Plant-Microbe Interact. 14:1213-1222.

Gaudriault, S., Malandrin, L., Paulin, J. P., and Barny, M. A. 1997. DspA, an essential pathogenicity factor of Erwinia amylovora showing homology with AvrE of Pseudomonas syringae, is secreted via the Hrp secretion pathway in a DspB-dependent way. Mol. Microbiol. 26:1057-1069.

Gaudriault, S., Brisset, M. N., and Barny, M. A. 1998. HrpW of Erwinia amylovora, a new Hrp-secreted protein. FEBS (Fed. Eur. Biochem. Soc.) Lett. 428:224-228.

Gaudriault, S., Paulin, J.-P., and Barny, M.-A. 2002. The DspB/F protein of Erwinia amylovora is a type III secretion chaperone ensuring efficient intrabacterial production of the Hrp-secreted DspA/E pathogenicity factor. Mol. Plant Pathol. 3:313-320.

Glasner, J. D., Liss, P., Plunkett, G., Darling, A., Prasad, T., Rusch, M., Byrnes, A., Gilson, M., Biehl, B., Blattner, F. R., and Perna, N. T. 2003. ASAP, a systematic annotation package for community analysis of genomes. Nucl. Acids Res. 31(1):147-151.

Greenberg, J. T., and Vinatzer, B. A. 2003. Identifying type III effectors of plant pathogens and analyzing their interaction with plant cells. Curr. Opin. Microbiol. 6:20-28.

Haseloff, J., Siemering, K. R., Prasher, D. C., and Hodge, S. 1997. Removal of a cryptic intron and subcellular localization of green fluorescent protein are required to mark transgenic Arabidopsis plants brightly. Proc. Natl. Acad. Sci. U.S.A. 94:2122-2127.

Hauck, P., Thilmony, R., and He, S. Y. 2003. A Pseudomonas syringae type III effector suppresses cell wall-based extracellular defense in susceptible Arabidopsis plants. Proc. Natl. Acad. Sci. U.S.A. 100:8577-8582.

Holeva, M. C., Bell, K. S., Hyman, L. J., Avrova, A. O., Whisson, S. C., Birch, P. R. J., and Toth, I. K. 2004. Use of a pooled transposon mutation grid to demonstrate roles in disease development for Erwinia carotovora subsp. atroseptica putative type III secreted effector (DspE/A) and helper (HrpN) proteins. Mol. Plant-Microbe Interact. 17:943-950.

Hood, E. E., Helmer, G. L., Fraley, R. T., and Chilton, M. D. 1986. The hypervirulence of Agrobacterium tumefaciens A281 is encoded in a region of pTiBo542 outside of T-DNA. J. Bacteriol. 168:1291-1301.

Hood, E., Gelvin, S., and Melchers, L. A. H. 1993. New Agrobacterium helper plasmids for gene transfer to plants. Transgenic Res. 2:208-218.

Jackson, R. W., Athanassopoulos, E., Tsiamis, G., Mansfield, J. W., Sesma, A., Arnold, D. L., Gibbon, M. J., Murillo, J., Taylor, J. D., and Vivian, A. 1999. Identification of a pathogenicity island, which contains genes 
for virulence and avirulence, on a large native plasmid in the bean pathogen Pseudomonas syringae pathovar phaseolicola. Proc. Natl. Acad. Sci. U.S.A. 96:10875-10880.

Jamir, Y., Guo, M., Oh, H. S., Petnicki-Ocwieja, T., Chen, S., Tang, X., Dickman, M. B., Collmer, A., and Alfano, J. R. 2004. Identification of Pseudomonas syringae type III effectors that can suppress programmed cell death in plants and yeast. Plant J. 37:554-565.

Jin, Q., and He, S. Y. 2001. Role of the Hrp pilus in type III protein secretion in Pseudomonas syringae. Science 294:2556-2558.

Jin, Q., Hu, W., Brown, I., McGhee, G., Hart, P., Jones, A. L., and He, S Y. 2001. Visualization of secreted Hrp and Avr proteins along the Hrp pilus during type III secretion in Erwinia amylovora and Pseudomonas syringae. Mol. Microbiol. 40:1129-1139.

Keshavarzi, M., Soylu, S., Brown, I., Bonas, U., Nicole, M., Rossiter, J., and Mansfield, J. 2004. Basal defenses induced in pepper by lipopolysaccharides are suppressed by Xanthomonas campestris pv. vesicatoria. Mol. Plant-Microbe Interact. 17:805-815.

Kim, J. F., and Beer, S. V. 1998. HrpW of Erwinia amylovora, a new harpin that contains a domain homologous to pectate lyases of a distinct class. J. Bacteriol. 180:5203-5210.

Klement, Z. 1982. Hypersensitivity. Pages 149-177 in: Phytopathogenic Prokaryotes. Academic Press, New York

Lamb, C. J., Ryals, J. A., Ward, E. R., and Dixon, R. A. 1992. Emerging strategies for enhancing crop resistance to microbial pathogens. Biotechnology (N Y) 10:1436-45.

Lespinasse, Y., and Aldwinckle H. S., 2000. Breeding for resistance to fire blight. Pages 253-273 in: Fire Blight. The Disease and Its Causative Agent, Erwinia amylovora. J. L. Vanneste, ed. CABI Publishing, New York.

Li, C. M., Brown, I., Mansfield, J., Stevens, C., Boureau, T., Romantschuk, M., and Taira, S. 2002. The Hrp pilus of Pseudomonas syringae elongates from its tip and acts as a conduit for translocation of the effector protein HrpZ. EMBO (Eur. Mol. Biol. Org.) J. 21:1909-1915.

Lopez-Solanilla, E., Bronstein, P. A., Schneider, A. R., and Collmer, A. 2004. HopPtoN is a Pseudomonas syringae Hrp (type III secretion system) cysteine protease effector that suppresses pathogen-induced necrosis associated with both compatible and incompatible plant interactions. Mol. Microbiol. 54:353-65.

Lorang, J. M., and Keen, N. T. 1995. Characterization of avrE from Pseudomonas syringae pv. tomato: A hrp-linked avirulence locus consisting of at least two transcriptional units. Mol. Plant-Microbe Interact. 8:49-57.

Lorang, J. M., Shen, H., Kobayashi, D., Cooksey, D., and Keen, N. T. 1994. avrA and avrE in Pseudomonas syringae pv. tomato PT23 play a role in virulence on tomato plants. Mol. Plant-Microbe Interact. 7:508515

Mor, H., Manulis, S., Zuck, M., Nizan, R., Coplin, D. L., and Barash, I. 2001. Genetic organization of the hrp gene cluster and $d s p A E / B F$ operon in Erwinia herbicola pv. gypsophilae. Mol. Plant-Microbe Interact. 14:431-436.

Paulin, J. P., and Samson, R. 1973. Le feu bactérien en France II. Caractères des souches d'Erwinia amylovora (Burril) Winslow et al. 1920 isolées du foyer franco-belge. Annu. Phytopathol. 5:389-397.

Perino, C., Gaudriault, S., Vian, B., and Barny, M. A. 1999. Visualization of harpin secretion in planta during infection of apple seedlings by $\mathrm{Er}$ winia amylovora. Cell Microbiol. 1:131-141.

Preston, G. M., Jackson, R. and Rainey, P.B. 2001. Characterization of the type III secreted protein RopE from Pseudomonas fluorescens SBW25. Mol. Microbiol. 41:999-1014.

Salanoubat, M., Genin, S., Artiguenave, F., Gouzy, J., Mangenot, S., Arlat,
M., Billault, A., Brottier, P., Camus, J. C., Cattolico, L., Chandler, M. Choisne, N., Claudel-Renard, C., Cunnac, S., Demange, N., Gaspin, C., Lavie, M., Moisan, A., Robert, C., Saurin, W., Schiex, T., Siguier, P., Thebault, P., Whalen, M., Wincker, P., Levy, M., Weissenbach, J., and Boucher, C. A. 2002. Genome sequence of the plant pathogen Ralstonia solanacearum. Nature 415:497-502.

Sambrook, J., Fritsch, E., and Maniatis, T. 1989. Molecular Cloning: A Laboratory Manual, 2nd ed. Cold Spring Harbor Laboratory, Cold Spring Harbor, NY. U.S.A.

Simonich, M. T., and Innes, R. W. 1995. A disease resistance gene in Arabidopsis with specificity for the avrPph3 gene of Pseudomonas syringae pv. phaseolicola. Mol. Plant-Microbe Interact. 8:637-640.

Steinberger, E. S., and Beer, S. V. 1988. Creation and complementation of pathogenicity mutants of Erwinia amylovora. Mol. Plant-Microbe Interact. 1:135-144.

Tao, Y., Xie, Z., Chen, W., Glazebrook, J., Chang, H. S., Han, B., Zhu, T., Zou, G., and Katagiri, F. 2003. Quantitative nature of Arabidopsis responses during compatible and incompatible interactions with the bacterial pathogen Pseudomonas syringae. Plant Cell 15:317-330.

Thomson, N. R., Nasser, W., McGowan, S., Sebaihia, M., and Salmond, G. P. 1999. Erwinia carotovora has two KdgR-like proteins belonging to the $I c i \mathrm{R}$ family of transcriptional regulators: Identification and characterization of the RexZ activator and the $\mathrm{KdgR}$ repressor of pathogenesis. Microbiology 145:1531-1545.

Tsiamis, G., Mansfield, J. W., Hockenhull, R., Jackson, R. W., Sesma, A. Athanassopoulos, E., Bennett, M. A., Stevens, C., Vivian, A., Taylor, J. D., and Murillo, J. 2000. Cultivar-specific avirulence and virulence functions assigned to avrPphF in Pseudomonas syringae pv. phaseolicola, the cause of bean halo-blight disease. EMBO (Eur. Mol. Biol. Org.) J. 19:3204-3014.

Van den Ackerveken, G., Marois, E., and Bonas, U. 1996. Recognition of the bacterial avirulence protein AvrBs3 occurs inside the host plant cell. Cell 87:1307-1316.

Van der Swet, T., and Beer, S. V. 1995. Fire Blight-Its nature, prevention, and control. A practical guide to integrated disease management. United States Department of Agriculture Information Bulletin No. 631; United States Department of Agriculture, Washington, D.C.

Venisse, J. S., Gullner, G., and Brisset, M. N. 2001. Evidence for the involvement of an oxidative stress in the initiation of infection of pear by Erwinia amylovora. Plant Physiol. 125:2164-2172.

Venisse, J.-S., Malnoy, M., Faize, M., Paulin, J.-P., and Brisset, M.-N. 2002. Modulation of defense responses of Malus spp. during compatible and incompatible interactions with Erwinia amylovora. Mol. PlantMicrobe Interact. 15:1204-1212.

Venisse, J.-S., Barny, M. A., Paulin, J.-P., and Brisset, M.-N. 2003. Involvement of three pathogenicity factors of Erwinia amylovora in the oxidative stress associated with compatible interaction in pear. FEBS (Fed. Eur. Biochem. Soc.) Lett. 537:198-202.

Warren, R. F., Merritt, P. M., Holub, E., and Innes, R. W. 1999. Identification of three putative signal transduction genes involved in $R$ genespecified disease resistance in Arabidopsis. Genetics 152:401-412.

Wei, Z. M., Laby, R. J., Zumoff, C. H., Bauer, D. W., He, S. Y., Collmer, A., and Beer, S. V. 1992. Harpin, elicitor of the hypersensitive response produced by the plant pathogen Erwinia amylovora. Science 257:85-88

Zhao, B., Ardales, E. Y., Raymundo, A., Bai, J., Trick, H. N., Leach, J. E., and Hulbert, S. H. 2004. The avrRxol gene from the rice pathogen Xanthomonas oryzae pv. oryzicola confers a nonhost defense reaction on maize with resistance gene Rxo1. Mol. Plant-Microbe Interact. 17:771779. 